\title{
O CORPO ESCRAVO: UMA ESCRITA VIVA NO DISCURSO MACHADIANO
}

\section{THE SLAVE BODY: A LIVING WRITING IN THE "MACHADIANO" DISCOURSE}

\author{
Profa. Dra. Geralda Medeiros Nóbrega \\ Profa Dra. Marluce Pereira da Silva \\ Prof. Dr. Luciano Barbosa Justino
}

RESUMO: Pretendemos analisar o conto "Pai contra mãe" de Machado de Assis, discutindo a memória da escravidão no Brasil. Situamos o corpo pela importância que dele advém, manifestada em corporeidades atuantes, demonstrando que o corpo tem memória e a história de cada um está registrada nele. As relações de poder atingem-no na sua totalidade e o plano simbólico explicita um estilo que desenvolve a falta de humanidade, destacando a violência revelada de modo generalizado.

PALAVRAS-CHAVE: Corpo, Imaginário, Escravidão, Memória.

ABSTRACT: We intend to analyze the short story "Pai contra mãe" by Machado de Assis, discussing the memory of slavery in Brazil. We situated the body according to the importance that comes from it, expressed in active bodies, showing that the body has memory and the history of everyone is recorded in the body. The power relationships affect the body in its totality and the symbolic plan mentions a style that develops the lack of humanity focusing the violence revealed in a widespread way.

KEY WORDS: Body, Imaginary, Slavery, Memory.

* Professora Titular da Universidade Estadual da Paraíba (UEPB). Doutoradoem Letras.gmnobrega@uolcom.br

* Professora Adjunta da Universidade Federal do Rio Grande do Note (UFRN). Doutorado em Letras. marlucepereira@uol.com.br

* Professor Adjunto da Universidade Estadual da Paraíba (UEPB). Doutorado em Letras. lucianobjustino@hotmail.com 



\section{O CORPO ESCRAVO: UMA ESCRITA VIVA \\ NO DISCURSO MACHADIANO}

\section{Introdução}

O conto "Pai contra mãe" da obra Relíquias de casa velha (1906), do escritor Machado de Assis, apresenta como personagens de destaque Cândido, que vive de subemprego, estabelecendo-se "com o ofício de pegar escravos". Emprego insuficiente para manter o filho recém-nascido. A outra personagem é mulher, chama-se Arminda, é mulata, escrava fugida e está grávida. A narrativa circunscreve-se em torno destas duas personagens e o narrador, desenvolvendo estratégias de resistência comprometidas com a história, reinscreve o imaginário social sob um olhar irônico dos interstícios da memória: "A escravidão levou consigo ofícios e aparelhos, como terá sucedido a outras instituições sociais. Não cito alguns aparelhos senão por se ligarem a certo ofício" (p. 9).

A memória veicula a ironia como um modo de ver o mundo. De fato "Às vezes a ironia pode mesmo ser interpretada como uma retirada de afeto, às vezes, entretanto, há um engajamento deliberado de emoção" (HUTCHEON, p. 33). A ironia, qualquer que seja a sua perspectiva, afeta todo o discurso machadiano, atuando em suas arestas como um artifício utilizado pelo narrador para prender a atenção do leitor. O conto critica o indivíduo e a sociedade escravocrata, de onde emana todo o componente da 
crueldade, amealhada desde os idos de 1570. Segundo Moreira et al (2006, p. 8), "Africanos e seus descendentes foram importantes personagens dos mundos do trabalho e da cultura urbana do século XIX. Inventaram territórios urbanos e diásporas, redefinindo identidades". Foram as cidades negras entre as quais se destacaram além do Rio de Janeiro, Salvador, Recife, São Luís e Porto Alegre, segundo informação dos autores supracitados.

O Rio de Janeiro, que sobressai na criação das cidades negras, trabalhado pelo narrador machadiano, compraz-se na sistemática geral da escravidão, como quando cita os aguilhões de castigo impostos aos escravos, fazendo sobressair o corpo, submetido à disciplina vista como "uma técnica de poder, que implica uma vigilância perpétua e constante dos indivíduos". (FOUCAULT, 1999a, p. 106). É um corpo pensado pelo narrador e um "corpo-texto em relação aos escravos, corpo-simbólico, imagem da dor". Corpo, duplamente submetido ao panóptico: vigiado pelo senhor de escravo e neste contexto, vigiado também por Cândido. Está, pois, num "estado consciente e permanente de visibilidade que assegura o funcionamento automático do poder" (FOUCAULT, 1999b, p. 166).

O excerto abaixo parece ilustrar a instalação desse panoptismo:

Um deles era o ferro ao pescoço, outro o ferro ao pé; havia também a máscara de folha-de-flandres. A máscara fazia perder o vício da embriaguez aos escravos, por lhes tampar a boca. Tinha só três buracos, dois para ver, um para respirar, e era fechada atrás da cabeça por um cadeado. Com o vício de beber, perdiam a tentação de furtar, porque geralmente era dos vinténs do senhor que eles tiravam com que matar a sede e aí ficavam dois pecados extintos, a sobriedade e a honestidade certas. Era grotesca tal máscara, mas a ordem social e humana nem sempre se alcança sem o grotesco, e alguma vez o cruel. Os funileiros as tinham penduradas, à venda, na porta das lojas, mas não cuidemos de máscaras. // O ferro ao pescoço era aplicado aos escravos fujões. Imaginai uma coleira grossa, com a haste grossa também, à direita ou à esquerda, até ao alto da cabeça e fechada atrás com chave. Pesava, naturalmente, mas era menos castigos que sinal. Escravo que fugia assim, onde quer que andasse, mostrava um reincidente, e com pouco era pegado (p. 9).

A seqüência detalhada dos instrumentos de castigo ou tortura é em si mesma a instauração de uma dupla ironia, pois, ao mesmo tempo "que ilumina o teatro do texto [...] faz denúncias e demonstra a necessidade 
de mudanças [...], exibe os artifícios de sua criação e valoriza o receptor, alteridade com quem deseja estabelecer comunicação" (DUARTE, 2006, p. 49).

Como a ordem social e humana pode estar submetida ao grotesco e ao cruel, fora de qualquer cogitação ética, como forma de redimir ou valorizar o que há de humanidade no indivíduo? O corpo tornando-se objeto, reificado, distante daquela relação de que fala Bourdieu (2004, p. 209): "Essa relação com o corpo é solidária com toda relação com o mundo [...]". Como estabelecer solidariedade com um corpo preso aos grilhões da escravidão? Eis por que a ironia ativa com a força de uma personagem, porque a alusão contínua ao sofrimento, como algo corriqueiro é seqüencial e constante. Mas a ironia se intensifica quando "não só o contexto, mas também a comunidade discursiva figura na compreensão de marcadores de ironia" (HUTCHEON, 2000, p. 218):

Há meio século, os escravos fugiam com freqüência Eram muitos, e nem todos gostavam de escravidão. Sucedia ocasionalmente apanharem pancada e nem todos gostavam de apanhar pancada (p. 9).

Um imaginário que pode ser visto como o imaginário da dor é, na sua rudeza, apanágio de uma memória historicizada. E através da História, sabe-se que os escravos não podiam rebelar-se, mas conseguiam transgredir o estabelecido, embora fossem obrigados a submeter a uma rígida disciplina. O narrador perpassa o imaginário, enxertado com imagens de um real ardiloso, encaminhado para o plano simbólico, que traz à tona um poder coercitivo, que deixava o outro impotente num tempo penoso, pacientemente suportável. É uma memória que, na ótica de Seixas (2004, p. 41), é exilada e por isto busca refúgio na história.

A memória na história e na narrativa é vista por Seixas, (2004, p. 49), como exilada e por isso busca refúgio na História. Logo "os lugares da memória (de uma memória que apenas vive sob o olhar de uma história reconstituída) como seu grande testemunho". O vento da barbárie, soprando sobre os escombros do passado, "revive a história. Não é uma coisa boa de ser lembrada, pois é uma memória traumática. Apesar de tudo, tentase dizer, narrativa e literatura de testemunho, que se tornaram um gênero tristemente recorrente [...]"(GAGNEBIN, 2004, p. 86). 


\section{A discriminação não se dilui no presente}

A indivisibilidade que se manifesta como "indivisibilidade social do afrobrasileiro manifesta-se, ainda, na incapacidade de enxergá-lo fora dos papéis sociais a ele destinados pela sociedade" (SOUZA, 2005, p. 35). São os laivos de um passado redivivo que introjeta no presente as marcas da exclusão. Daí por que é comum que um número majoritário de negros exerçam "funções de subalternidade em empregos da baixa remuneração [...] situações em que quase não são notados como pessoas, fazem parte do cenário - são invisíveis" (SOUZA, 2005, p. 35). Ainda de acordo com a estudiosa acima citada, "o antropólogo Kabengele Munanga entende o silenciamento sobre as desigualdades raciais como um traço da ideologia da democracia racial brasileira que leva os brasileiros a negar a discriminação e que em nada abala a eficácia da exclusão" (2005, p. 49).

A personagem, Cândido Neves, é um títere manipulado pelo narrador. Este é um recurso utilizado para colocar o leitor frente a si mesmo para se inserir no tema, captando do outro a possibilidade do relacionamento de um nós e um outro. Cândido é uma voz que usa a ironia como sátira, e faz que o outro se multiplique:

Você passa semanas sem vintém.

- Sim, mas lá vem uma noite que compensa tudo, até de sobra. Deus não me abandona, o preto fugido sabe que comigo não brinca; quase nenhum resiste, muitos se entregam logo.

Tinha glória nisto, falava da esperança como de capital seguro. Daí a pouco ria, e fazia rir à tia, que era naturalmente alegre, e previa uma patuscada no batizado (p. 11).

Cândido Neves é uma espécie de panóptico ambulante, que atua como "laboratório de poder". "O panóptico [...] deve ser compreendido como modelo generalizável de funcionamento; uma maneira de definir as relações com a vida cotidiana dos homens" (FOUCAULT, 1999a, p. 169-70). Aqui, especificamente, o panóptico está na dependência da argúcia de Candinho, submetida à capacidade imaginária do narrador e constatando o pensamento de Foucault, o panóptico é "polivalente em suas aplicações".

Cândido Neves tinha boa memória. Por isso, "fixados os sinais e os costumes de um escravo fugido, gastava pouco tempo em achá-lo, segurá-lo, amarrá-lo, e levá-lo. A força era muita, a agilidade também”. (p. 12-13). 
O negro bem poderia dizer de si mesmo: eu sou o que sou, isto é, negro fugido. Arminda, pois, é um eu em busca de si mesmo, navegando pelos caminhos da alteridade, em busca de compreender o que nem ele mesmo sabe identificar, modo inconsciente de buscar a liberdade, num "corpo" fechado em si mesmo em sua identidade, numa perspectiva de Merleau-Ponty. Por isso, podemos perguntar: Onde se situa a presença de humanidade que valoriza o humano em situações de alteridade?

Faltava a Arminda o povo da comunidade. Bauman lembra que "não ter comunidade significa não ter proteção" e diz ainda que "a segurança e a liberdade são dois valores igualmente preciosos e desejados [...]", (2003, p. 10), o que não sói acontecer a Arminda, que está indefesa e sozinha.

Uma atitude panóptica de Cândido Neves funcionava como uma técnica de esperteza. Quando via passar um escravo, que podia ser identificado como fugido, embora nem sempre permanecesse ileso, pois, fazendo uso de sua corporeidade, o escravo usava unhas e dente para se defender:

Não o apanhava logo, espreitava lugar azado, e de um salto tinha a gratificação nas mãos. Nem sempre saía sem sangue, as unhas e os dentes do outro trabalhavam, mas geralmente ele os vencia sem o menor arranhão (p. 13).

O corpo, na sua corporeidade, está manifesto como aquilo com o qual se pode lidar. É um corpo visual e um corpo tátil que se presentificam, contribuindo para a expansão do interdito, agora aclarado por Merleau-Ponty (1994, p. 251):

O sentido dos gestos não é dado, mas compreendido, [...], retomado por um ato do espectador. [...]. Obtém-se a comunicação ou a compreensão dos gestos pela reciprocidade entre minhas intenções e os gestos do outro, entre meus gestos e intenções legíveis na conduta do outro.

\section{0 corpo pensado $x$ o corpo sofrido}

O corpo subjetivado atinge a corporeidade, partindo de um corpo imaginário, que conectado ao corpo real, manifesta através de um corpo simbólico, atingindo a sua completude. Mas falar do sofrimento é falar do corpo propriamente dito, o que se explicitará quando situarmos Arminda. O corpo então passa a ser um "receptáculo de sensações" (SANTAELLA, 2004). 
Nasce o filho de Cândido Neves, que será exposto à doação "A alegria do pai foi enorme, e a tristeza também. Tia Mônica insistia em dar à criança à Roda. [...]. Notai que era um menino, e que ambos os pais desejavam justamente este sexo" (p. 15).

Cândido Neves sofre. "Há certamente um trânsito da consciência, que só se vê para si fechada e, por isso, só reflete a si mesma, para uma relação com a outra consciência. Nesse caso inicial é como pura cobiça" (DI NAPOLI, 2000, p. 234). E é a partir desta tomada de consciência que a personagem põe em risco a segurança da escrava fugida. "Tratava-se de uma mulata; vinham indicações de gesto e de vestido". Como o pagamento "[...] subia a cem mil réis"... "Agora, porém, a vista nova da quantia e a necessidade dela animaram Cândido Neves a fazer um grande esforço derradeiro" (p. 15).

A vontade agora, permeada pela sensação de poder, chega a bom termo, é estimulante. A personagem sabe ter chances de realizar o seu intento. E começa a caçada. A atitude panóptica se manifesta na agudeza do olhar e na perspicácia do caçador.

Este conto que, no seu âmago, exemplifica uma literatura de testemunho, é, no plano simbólico o supra sumo de uma memória centrada na História. Chalhoub (2007, p. 220) ao discutir o tema da escravidão destaca que:

Na segunda metade do século XIX, o problema era definir os direitos políticos dos descendentes de escravos [...] A solução à brasileira desse problema, criticada por abolicionistas e intelectuais de proa, como Joaquim Nabuco e Machado de Assis, foi elidir critérios raciais de exclusão a passar a exigir com modos rigorosos de aferição - a capacidade de ler e escrever para a qualificação de eleitores.

Os negros poderiam, então, votar. Algo que afirmaria a cidadania, o que Carvalho (2004, p. 75), menciona como "um esboço de cidadão, mesmo que em negativo" Isto, bem entendido, a partir de tentativas de participação política.

Observa-se um paradoxo no texto machadiano, que se manifesta pela distância entre a realidade e a ficção. $\mathrm{O}$ autor, que defende o escravo, utiliza um narrador frio, mas, ao mesmo tempo, podemos chamar a atenção para o fato de manipulação da ironia apontar para uma visão crítica à natureza humana. A perda de sentido de humanidade está patente na personagem Cândido que sobrepõe a necessidade financeira a qualquer sentimento 
humanitário que por ventura pudesse ter. O objetivo de sua ganância era ter dinheiro para manter o filho perto de si, uma criança a que falta ainda o nome, mas que promove uma "maneira de vivenciar" a situação de pobreza. É uma criança cuja identidade ainda não foi construída, mas pode afetar a estrutura de identidade outra que sequer chega a ser cogitada, como a do filho de Arminda que é abortado.

A situação de pobreza nivela o perseguidor e a perseguida. $\mathrm{O}$ primeiro forçado pela necessidade, sai à caça da escrava; esta anseia pela liberdade e o pelo direito de ser mãe. "O poder simbólico é um poder de fazer coisas com palavras". (BORDIEU, 2004, p. 166). As palavras movimentam o corpo ao som de um nome. Significa dizer à moda de Marzano-Parisoli (2004, p. 14), que "o corpo é o que nos permite encontrar os outros e que manifesta nossa natureza relacional pela afirmação de nossa individualidade". O narrador compreendeu essa realidade muito bem, ao inserir a personagem Cândido Neves que

viu do lado oposto um vulto de mulher; era a mulata fugida. Não dou aqui a comoção de Cândido Neves por não podê-lo fazer com a intensidade real. Um adjetivo basta; digamos enorme. (p. 16).

Importante destacar a visão maniqueísta que se estabelece, segundo a qual o que é bom para Cândido Neves se apresenta ruim para Arminda. A identidade da personagem se patenteia a partir do nome Arminda, nome que representa a sua perdição. Ao som de seu nome "Arminda voltou-se sem cuidar malícia" (p. 17).

\section{Identidade e pobreza}

Geertz (1989, p. 228) diz que "os problemas, sendo existentes, são universais; suas soluções, sendo humanas, são diversas”. De acordo com a visão de Geertz, o aspecto humano, diversificado na solução dos problemas, possibilita tomada de posições variadas. Em se tratando da situação de Arminda, o inusitado da situação interfere na significância do texto de modo doloroso. Indefesa, pede clemência que lhe é negada, o que prova que, para Arminda, a liberdade é um símbolo utópico uma vez que "a criação humana tem o poder de definir o racismo como diferenciação natural das desigualdades sociais" (RUIZ, 2006, p. 149): 
- Estou grávida, meu senhor! Exclamou. Se vossa Senhoria tem algum filho, peço-lhe por amor dele que me solte: eu serei sua escrava vou servi-lo pelo tempo que quiser. Me solte, meu senhor moço!

- Siga! Repetiu Cândido Neves.

- Me solte!

- Não quero demoras; siga. (p. 17)

A fragilidade da situação mostra que ela passaria de um dono para outro o que comprova que: "Lutamos a cada dia por construir ideais de vida e quando chegamos no que consideramos que é o topo de nossos objetivos caímos na conta de que temos que retornar a começar tudo de novo" (RUIZ, 2006, p. 87-8).

Logo, este texto abre perspectivas para novas visões de mundo, principalmente no que concerne a atitudes e tomadas de consciência, como o desejo de liberdade, o que, de acordo com o autor referendado, a liberdade do sujeito não é para fazer o que quiser, "mas para se comprometer com as interpelações do outro necessitado" (p. 103). Arminda ia alegando que o senhor era muito mau, e provavelmente a castigaria com açoites, coisa que, no estado em que ela estava, seria pior de sentir. Com certeza, ele lhe mandaria dar açoites. A corporeidade atua como conseqüência do medo, e a "relação com o corpo é solidária com toda relação com o mundo" (BORDIEU, 2004, p. 209), afetado aqui pelo direito de querer ser mãe.

O corpo de Arminda, acolhendo outro corpo, está agora exposto à violência. O que acontecerá ao corpo e a sua vida? Qualquer discurso sobre este curso se depara com a resistência da personagem e o narrador não lhe dá trégua, o que se apresenta como violência real exercida pelo corpo:

- Você é que tem culpa. Quem lhe manda fazer filhos e fugir depois? Perguntou Cândido Neves.

Arminda sabe o que lhe espera e por isso procura retardar a chegada. "Chegou, enfim, arrastada, desesperada, arquejando. Ainda ali ajoelhou-se, mas em vão. O senhor estava em casa, acudiu ao chamado e ao rumor”. (p. 17).

As identidades se manifestam como "uma rede de conexão" o que, segundo Bauman (2005, p. 44), "são identidades que estereotipam, humilham, desumanizam, estigmatizam...” o que, em relação a Cândido Neves é 
motivo para promover a persecução da mulata fugida, grávida e escrava.

Segundo Barthes (1980, p. 143): "podemos dizer que o próprio da narrativa não é a ação, mas o personagem como nome próprio: o material sêmico [...] vem preencher o próprio de ser; o nome, de adjectivos". A partir do nome, a personagem se avulta no conto: Com os braços presos é incitada a caminhar "pediu então que a soltasse pelo amor de Deus". Vitimizada, a escrava pede clemência.

A identidade pessoal de Arminda é como uma rede significativa construída em torno de seu corpo, o que pode se explicado através de Ruiz (2006, p. 127), quando lembra que o sujeito, através das práticas significativas, estabelece subjetividades que se inserem nas diversas esferas, através do referente histórico e das circunstâncias em que vive por meio das práticas de sentido. Para Ruiz (p. 127), "o sentido é uma criação simbólica que reveste as coisas com uma compreensão particular pela qual o sujeito pauta seu agir". Por siso, focalizamos Foucault (1999a) que fala de punição generalizada e lembra que o que deve ser respeitada na punição é a humanidade da vitima, e destaca, o exercício do poder, embora fique bem claro que o sentido subverte a humanidade para instalar a violência:

O espírito como superfície de inscrição para o poder, com a semiologia por instrumento; a submissão dos corpos pelo controle das idéias; a analise das representações como principio numa política dos corpos bem mais eficaz que a anatomia ritual dos suplícios (p. 86).

Como se manifesta em seguida:

- Aqui está a fujona, disse Cândido Neves.

- É ela mesma.

- Meu senhor.

- Anda, entra...

Foucault (1999b) discute a questão do corpo para introduzir a noção de emergência que se produz em um "determinado estado das forças", para acrescentar em seguida que: "Ninguém é, portanto responsável por uma emergência" (p. 22-4).

O corpo de Arminda, exposto à brutalização se torna dócil. O corpo escravo se submete ao domínio do outro para ser disciplinado. É um corpo que 
revela uma memória coletiva, social, corpo cujas marcas de sofrimento relacionadas à memória corporal são com feridas antigas ainda não cicatrizadas.

Acontece o (in)esperado, numa situação emergencial, em que a humanidade não foi resgatada. Foucault (1999a, p. 31) admite que "o corpo só se torna força útil se é ao mesmo tempo corpo produtivo e corpo submisso, par acrescentar em seguida, embora aplique seu discurso a outras circunstâncias;" o suplício na arte quantitativa do sofrimento. Mas não é só: esta produção é regulada”.

Arminda caiu no corredor. Ali mesmo o senhor da escrava abriu a carteira e tirou os cem mil-réis de gratificação. Cândido Neves guardou as duas notas de cinqüenta mil-réis, enquanto o senhor novamente dizia à escrava que entrasse. No chão onde jazia, levada do medo e da dor, e após algum tempo de luta a escrava abortou. $\mathrm{O}$ fruto de algum tempo entrou sem vida neste mundo, entre os gemidos da mãe e os gestos de desespero do dono (p. 17-8).

Cândido Neves recupera o direito de ficar com o primogênito, à custa do sofrimento da escrava que perde o filho. Até se poderia compreender a atitude da personagem se não fosse o comentário dele denotando total ausência de humanidade. Por isso, podemos dizer com Vignoles (1921, p. 1320): "a perversidade é então verdade privada de sentido, mas verdade da condição humana”. A instalação da perversidade se patenteia de modo cruel quando Cândido Neves diz: "- Nem todas as crianças vingam, bateulhe o coração" (p. 18).

\section{Conclusão}

Os aspectos simbólicos do corpo, na trajetória da narrativa, situam o escritor Machado de Assis como homem de seu tempo. Através de um narrador que marca a realidade com as cores da ironia, o escritor documenta aspectos da história que talvez passassem despercebidos se não fosse a acuidade inata da verve machadiana para estabelecer um monumento escritural em torno de temas ligados à escravidão que os livros didáticos ou teóricos, às vezes obscurecem, conforme pode ser ilustrado com o discurso do próprio conto:

Ora, pegar um escravo fugido era um ofício do tempo. Não seria nobre, mas por ser instrumento da força com que se mantém a lei e a propriedade, trazia esta outra nobreza implícita das ações reivindicadoras. Ninguém se metia em 
tal ofício por desfastio ou estudo; a pobreza, a necessidade de uma achega, a inaptidão para outros trabalhos, o acaso, e alguma vez o gosto de servir também, ainda que por outra via, davam impulso ao homem que se sentia bastante rijo para pôr orem à desordem (p. 6).

O corpo sofrido do escravo é um suporte para as marcas da escravidão e ausência total de humanidade define a própria condição humana. Mesmo reconhecendo que Machado de Assis parecia antever a realidade dos aspectos sociais e econômicos da estrutura injusta vigente, parece instruir o seu narrador para anular qualquer visão utópica que, porventura, os escravos pudessem ter. Arminda é vetora de um desejo latente de busca de liberdade para salvar seu filho, tentativa inútil, que amplia a dor e o sofrimento da perda irreparável. Então perguntamos: como continuar vivendo quando se perde também a esperança?

O narrador nada acrescenta, mas pudemos aquilatar a angústia de um momento em que medo e dor se imbricam, dando tonicidade a um a linguagem sensorial para registrar a perda da liberdade e a perda do filho. $\mathrm{O}$ imaginário, apreendendo o real, dimensiona o simbólico para significar o encontro da vida com a morte, como um abandono de Si mesmo a uma sorte mesquinha.

Em se tratando de Arminda, a identidade se torna flexível ou desdobrável, pois a sua nova situação abre um leque de possibilidade de ampliar a perspectiva identitária. Escrava capturada, mãe que perdeu o filho ainda em gestação, aquela que possivelmente será castigada. Identidade intersecionada, agora fragmentada, permitindo que as memórias corporais reapareçam trazendo lembranças passadas num presente que já aponta para um futuro sem nenhuma expectativa.

A questão que agora se apresenta diz respeito a uma correlação com o poder que permite ao sujeito construir seus modos de subjetivação, como estilo de vida. O corpo (res)sentido pelas marcas amargas da memória, se espacializa no tempo, quando a vigência simbólica, assumida por causa de sofrimento indizível e dores exacerbadas, permite inventar o presente.

O ressentimento então, pode ludibriar o esquecimento, única oportunidade de exercício de poder por parte de Arminda, agora um estereótipo de seus irmãos de consternação, se circunscrevendo todos aqueles cujas marcas corporais tenham resultado de dores menos intensas do que as dores espirituais, na sua corporeidade. 
No fim ainda indagamos: o que restou de Arminda? não damos respostas para que o nosso leitor complemente o que ora apresentamos.

\section{Referências Bibliográficas}

ASSIS, J.M.M. de. Relíquias de casa velha. São Paulo: Catania, s.d.

BARTHES, R. S/Z. Lisboa: Edições 70, [1980]

BAUMAN, Z. Comunidade. Rio de Janeiro. Jorge Zahar, 2003. Identidade. Rio de Janeiro: Jorge Zahar, 2005.

BOURDIEU, P. Coisas Ditas. São Paulo: Brasiliense, 2004.

CARVAlHO, J. M. de. Cidadania no Brasil: o longo caminho 6. ed. Rio de Janeiro: Civilização Brasileira, 2004.

CHALHOUB, S. Solidariedade e liberdade: sociedades beneficentes de negros e negras no Rio de Janeiro na segunda metade do século XIX. Jr: CUNHA, O.M.G.; GOMES, F. dos S. Quase-cidadão. Rio de Janeiro: Editora FGV, 2007.

DUARTE, L. P. Ironia e amor na literatura. Belo Horizonte: Ed. PUC Minas; São Paulo: Alameda, 2006.

FOUCAULT, M. Vigiar e punir: nascimento da prisão. Petrópolis: Vozes, $1999 \mathrm{a}$

. Microfísica do poder. 14a . ed. Rio de Janeiro: Graal, 1999b.

GAGNEBIN, J. M. Memória, história, testemunho. In: BRESCIANI, S.; NAXARA, M. (Org.). Memória e (res)sentimento: indagações sobre uma questão sensível. Campinas: Ed. da UNICAMP, 2004.

GEERTZ, C. A interpretação das culturas. Rio de Janeiro: Livros técnicos e Científicos, 1989.

HUTCHEON, L. Teoria e política da ironia. Belo Horizonte: Ed. UFMG, 2000. MARZANO-PARIZOLI, M. M. Pensar o corpo. Petrópolis: Vozes, 2004.

MERLEAU-PONTY, M. Fenomenologia da percepção. São Paulo: Martins Fontes, 1994.

MOREIRA, C. E. [et al]. Cidades negras: africanos, crioulos e espaços urbanos no Brasil escravista do século XIX. São Paulo: Alameda, 2006. 
RUIZ, C. M.M.B. As encruzilhadas do humanismo: a subjetividade e alteridade ante os dilemas do poder ético. Petrópolis: Vozes, 2006.

SANTAELLA, L. Corpo e comunicação. São Paulo: Paulus, 2004.

SEIXAS, J.A.de. Percursos de memórias em terras de história: problemáticas atuais. In. BRESCIANI, S.; NAXARA, M. (Org.). Memória e (res)sentimento: indagações sobre uma questão sensível. Campinas: Ed. da UNICAMP, 2004.

SOUZA, F. da S. Afro-descendência em cadernos negros e jornal do MNU. Belo Horizonte: Autêntica, 2005.

VINOLES, P. A perversidade. Campinas: Papirus, 1991. 
